\title{
2 Britain and Africa after the Cold War
}

\author{
Beyond damage limitation?!
}

\author{
Paul Williams
}

Ever since Britain's retreat from colonialism in Africa got underway in earnest the primary concern of successive governments towards the continent has been aptly summarized by James Mayall as one of damage limitation. During this period, Mayall (1986) argued, Britain's Africa policy revolved around the need to turn its imperial legacies 'from liabilities into assets'. This required the creation of 'a network of low key, but still special, relationships between Britain and her former colonies' (1986: 54). Successive British governments pursued this goal through three main mechanisms: the organization and management of the international economy; bilateral relations - primarily economic in character; and the political organization of international society.

Fundamentally, little has changed in Britain's relationship with Africa after the Cold War. More sympathetic interpretations of Britain's Africa policy have described it as 'reactive rather than proactive' and 'pragmatic in the extreme' (Spence in Styan 1996: 262), but it remains true to say that the Thatcher, Major and Blair governments have all been primarily concerned with damage limitation of one sort or another. In this sense, each government inherited the traditional post-colonial British mindset that saw Africa 'as a source of trouble rather than opportunity' (Clapham 1996: 88). It is also the case that each administration has used the familiar tools of economic, political and bilateral leverage to ensure their relations with African states run smoothly. But while the objectives and methods of Britain's Africa policy display a large degree of continuity, they are no longer so strictly confined to so-called anglophone or Commonwealth Africa, especially since the election of Tony Blair's New Labour Party in May 1997. Along with the scope, the discourse and language used to present and describe British foreign policy has also changed after the Cold War (see Williams 2002). This development is not unique to Britain but is representative of the language adopted by most Western states with a declared commitment to promoting liberal values abroad (Kahler 1997). After the disintegration of the Soviet Union and the concomitant increase in the power of neo-liberalism, British officials have presented their Africa policy as being fundamentally concerned with the promotion of peace, prosperity 
and democracy on the continent. More recently still, and particularly after 11 September 2001, the reasons for serious engagement with Africa have increasingly been wrapped up in the language of 'threats', 'risks' and 'security' (see Abrahamsen 2002). Britain's Africa policy is thus once again displaying a primary concern with damage limitation.

This chapter provides a critical evaluation of Britain's Africa policy after the Cold War with reference to the three themes of peace, prosperity and democracy. But first it is necessary to describe the evolving context within which these policy themes have been developed and their implementation attempted.

\section{What is the political context for Britain's Africa policy?}

In 1996, David Styan (1996: 261) noted how 'Africans and students of Africa will search in vain for sustained debates or literature on contemporary British policy in Africa'. Today, there are tentative signs that this situation is changing, but Styan's point is indicative of the fact that Africa has not been a priority for Britain's foreign policy elites for several decades. Their attention has consistently focused on other parts of the world, especially Europe, the former Soviet Union and East Asia. South Africa, Zimbabwe and (briefly) Sierra Leone are the only African states that have temporarily become major issues in Britain's post-Cold War foreign policy. But this lack of priority does not mean, as is sometimes suggested, that Britain has had no African policy, only that it has been of marginal concern to the major players in Westminster and Whitehall.

This lack of concern has been reflected in several trends in Britain's relationship with Africa. During the Conservative years (1989-97), while Britain increased its diplomatic engagement with eastern European and successor states of the Soviet Union, the number and size of diplomatic missions in Africa were reduced (five were closed in 1991 alone) against, it should be noted, the advice of those diplomats with significant expertise on the continent. ${ }^{2}$ Little information was widely available on the topic; budgets were cut (including a reported 18 per cent cut on spending on Africa between 1994 and 1997); and policy became almost solely the concern of the Overseas Development Administration (ODA), which encouraged a tendency within Whitehall to see African policy as being synonymous with the British aid programme and for policy to be heavily influenced by the former de facto 'Minister of Africa', Lynda Chalker at the head of the ODA (Styan 1996: 262-3, 266). African issues have since climbed higher up Britain's foreign policy agenda under the New Labour government (1997-present), culminating in a series of speeches and policy documents that suggested the continent was 'a scar on the conscience of the world' and was urgently in need of international support (Blair 2001). In practice, however, African affairs have rarely been a priority for British politicians or makers of foreign policy. As one Kenyan parliamentary group visiting London in 1998 
lamented, virtually no one in the British parliament had any knowledge about contemporary events in Kenya (Khadiagala 2000: 101). One suspects this holds true for the vast majority of African countries.

Not only has Africa been a marginal concern for British foreign policy, when it has attracted greater attention, policy has concentrated upon certain parts of the continent and neglected others. First, British policy has split the continent into two parts, with separate concerns and ministerial structures for dealing with North Africa and the Mahgreb, and Africa south of the Sahara. Within policy circles, Britain's Africa policy is usually taken as shorthand for policy towards sub-Saharan Africa. This chapter also follows this convention. Second, within sub-Saharan Africa, British aid, trade, investment and interests have been concentrated, at times almost exclusively, on Commonwealth Africa. The most startling example of this tendency was the almost total indifference displayed by John Major's government to the 1994 Rwandan genocide. Since Rwanda was deemed to lie outside its zone of interest, the signals from London to British diplomats in the region were that this was a 'country of which we knew little and cared less'. ${ }^{3}$ At the time, the Foreign Secretary, Douglas Hurd, was apparently preoccupied coaxing the eastern Europeans 'into the same bed as the West'; selling the idea of a less interfering but benevolent EU to his party and public; and maintaining unity within the Conservative Party (Economist 12 March 1994: 34).

It is hardly surprising that on such a large and diverse continent policy should be concentrated upon a few key states. Until very recently, with the exception of Nigeria, British policy has focused upon southern and east Africa, particularly South Africa, Kenya, Zimbabwe and Uganda. Apart from a few minor initiatives in 1994, it was only after the Anglo-French summit at St Malo in December 1998 that a significant declaration was made to move beyond the mindset of post-imperial spheres of influence in Africa with regard to British and French policy towards the continent. This change in policy would, it was claimed, include greater cooperation and the sharing of information and diplomatic premises. Yet arguably even this symbolic step towards a more coordinated Anglo-French policy in Africa was a reaction to growing US influence in world politics in general and in their former African colonies in particular. Moreover, little practical evidence has emerged of moving beyond a 'spheres-of-influence' approach, with Britain and France subsequently disagreeing over policies on the wars in the Democratic Republic of Congo (DRC), Liberia and Sierra Leone (Ero 2001: 63-5) and how best to deal with Zimbabwe's President Robert Mugabe.

A third significant contextual factor is the way in which throughout the post-Cold War era the British state has worked in tandem with a variety of non-state actors including transnational corporations (TNCs), humanitarian and development NGOs and international organizations to pursue its policies. Under the Conservatives there was little evidence of close partnerships with humanitarian NGOs. Indeed, the Foreign and Commonwealth Office (FCO) was keen to retain as much control over foreign policy as possible. 
This included letting as few 'outsiders' as possible become genuinely involved in the policy-making process. In contrast, New Labour has developed a much closer working relationship with numerous humanitarian and development NGOs, including a steady flow of staff exchanges with Amnesty International and Save the Children. On the economic dimensions of policy, especially trade and investment, both Conservative and Labour governments have actively promoted British TNCs and worked closely with the country's business elites through such organizations as the Commonwealth Development Corporation, the Confederation of British Industry, Trade Partners UK and the British Overseas Trade Board. The British state has also pursued its objectives through a variety of multilateral institutions. The most important of these in relation to the promotion of peace, prosperity and democracy in Africa have been the United Nations (UN), the International Monetary Fund (IMF) and World Bank, the Commonwealth, the European Union (EU) and the G-7/8.

The impact of the two main political parties, Conservative and Labour, on Britain's post-Cold War Africa policy also merits consideration. Although the attributes each party brings to Africa policy are difficult to quantify, the different concerns and traditions of the Conservative and Labour governments do appear relevant. At a general level, during the 1990s the Conservatives spent much of their period in office with a slim parliamentary majority. Consequently, the party's attention was focused on domestic issues, internal bickering over who should lead the party, and Britain's relationship with the European Community (see Wallace 1994). In contrast, New Labour swept to power with a massive majority and devoted far more attention to international issues, not least because of the efforts of the Foreign Secretary, Robin Cook, and because, in comparison with John Major, Tony Blair's political philosophy gave ideas of globalization and international interdependence central roles (see Blair 1997, 1998). Under New Labour, African affairs have received considerably more attention and funds than under the Major government, although in policy terms evidence of continuity is greater than of a fundamental change of direction (Abrahamsen and Williams 2001, 2002). Arguably the most important institutional difference between the two parties is New Labour's establishment of the Department for International Development (DFID), which has devoted considerable time and resources to African affairs. As noted above, under the Conservatives the ODA (DFID's predecessor) was run as an autonomous wing of the FCO.

The final contextual factor relates to the representation of Africa in the British media. Over the course of the 1990s trends in British media coverage of Africa have helped frame public discussion about Britain's relationship with the continent. Within Western media outlets, coverage of international affairs in general has significantly reduced after the Cold War. In relation to Africa, there are also far fewer expert Africa correspondents. The result has been a marked deterioration in both the quantity and quality of journalistic 
writing from and on Africa. In addition, the continent has been plagued by the editorial tendency to adopt a 'coups and catastrophes' approach to African affairs (Styan 1996: 276). On the rare occasions when the media spotlight has been turned on Africa it has been incredibly selective in its choice of issues worthy of reporting and has often bought into simplistic and stereotypical perspectives about the role of tribes, ethnicity, corruption and religion in Africa, especially in the descriptions of the continent's recent conflicts. This was particularly evident in the early journalistic descriptions of the 1994 Rwandan genocide (see McNulty 1999; Melvern 2001). As with other parts of the world, stable and flourishing political systems have not been considered newsworthy. But unlike other parts of the world, Africa has been consistently characterized as 'hopeless' (Economist 13 May 2000). Similarly, while some wars, coups and fraudulent elections have attracted the media's gaze, others have been neglected. And yet the issue that has attracted the greatest volume of media commentary in Britain - refugees seeking political asylum and immigration more generally - has been discussed with little reference to the terrible political circumstances which force many Africans to leave their homes in the first place (see Styan 1996: 278-82). This has meant that the minority of the British public interested in African affairs has been shown the continent through a very restricted and simplistic set of lenses. In relation to policy, combined with the reduction in diplomatic personnel based in Africa, media trends have meant that NGOs such as the International Crisis Group and Human Rights Watch have become far more important as sources of information about current events.

\section{What are the objectives of Britain's Africa policy?}

After the end of the Cold War and the collapse of the Soviet Union a renewed power and self-confidence came over Western states, Britain included. This proved the catalyst for a raft of announcements stating principles about aid conditionality, good government and human rights. In June 1990, for example, Foreign Secretary Douglas Hurd publicly declared the need for economic development and 'good governance' to go hand in hand. In his words, 'economic success depends extensively on the existence of an efficient and honest government, on political pluralism and, I would like to add, respect for the law and free and more open economies' (Hurd 1990). Hurd continued to explicitly link these ideas to the goals of British foreign policy. 'Countries which tend towards pluralism, public accountability, respect for human rights and market principles,' he argued, 'should be encouraged. Governments which persist with repressive policies, corrupt management and wasteful, discredited economic systems should not expect us to support their folly with scarce aid resources which could be used better elsewhere' (Hurd 1990).

In many respects, these sentiments set the ideological tone that continues to shape Britain's Africa policy today. In this sense, the principal objectives 
of Britain's Africa policy after the Cold War have been relatively consistent, at least at the theoretical level.

These same priorities were reiterated in 1995 by Lynda Chalker, who presented British policy as having five main objectives: the promotion of 'good governance', economic reform and the alleviation of poverty; support for the peaceful resolution of conflicts; international cooperation over criminal activities in Africa (notably drugs, terrorism and illegal immigration); support for the new democratic order in South Africa; and furthering British commercial interests (in Styan 1996: 264). As Styan (1996: 264) noted, the core themes were economic reform, growth and governance; the commercial interests of British trade and investment; and bilateral relations with South Africa. In comparison, conflict resolution and combating criminal activities were far less of a priority.

Over the course of New Labour's period in office the excessive focus on South Africa has diminished and the themes of conflict resolution and prevention have assumed greater prominence. But the concern with economic growth, reform and governance and other commercial interests remains central. In addition, New Labour ministers have placed a greater weight on the need to promote human rights than had been evident in the pronouncements of the previous Conservative government. However, it soon became evident that the Blair government's Africa policy would revolve around the promotion of the three interrelated concepts of peace, prosperity and democracy. These were said to be the three key challenges facing Africa in the twenty-first century (see Cook 1998; Hain 1999a).

\section{Promoting peace?}

Without peace there can be little hope of establishing durable democracy and sustainable development in Africa. Unfortunately, Britain's post-Cold War attempts to promote peace in Africa have been selective, inconsistent, under-resourced, narrowly focused and preoccupied with managing rather than preventing violent conflicts. However, there have been positive results, including attempts to regulate conflict trade goods such as diamonds and recent suggestions that more attention, and crucially more (human and financial) resources, will be devoted to conflict prevention.

During the Conservative years, Britain significantly disengaged from the continent as both its economic and geostrategic interests there dwindled. Within this context, John Major's government devoted only marginal attention and resources to promoting peace in Africa and at times pursued policies counterproductive to its stated aims. Ironically, Major was one of the few British prime ministers who had hands-on experience in Africa, having worked in Nigeria. On the positive side, some 650 British troops participated in the UNAVEM III operation in Angola and the government provided more than $£ 36 \mathrm{~m}$ of aid to help provide relief, food, shelter, demining and to demobilize soldiers (FCO 1995). The British government also 
contributed to a UN trust fund to help pay for ECOMOG's activities in Liberia; provided police training to over thirty African countries; and started deploying military advisory training teams (BMATTs) more heavily outside anglophone Africa, including to Angola and Mozambique. In November 1994, Major also endorsed French President François Mitterand's proposal made at the Franco-African summit that 1,000-1,500 African troops should be trained, equipped and financed for peacekeeping duties by France and other European powers, and eventually by the EU. Britain's initiative was aimed at establishing structures to prevent conflict and manage crises as they arose; help African states train their troops for peacekeeping; and support provision of equipment and logistics to enable rapid deployment (Rifkind 1996: 630).

But these positive developments were overshadowed by other less constructive policies. Despite calling for peace, Major's government continued to sell weapons to a variety of African states, including regimes that openly flouted democratic principles and human rights standards. For instance, although Britain provided military instructors to help train the post-apartheid South African armed forces, in early 1995 the British Defence Secretary, Malcolm Rifkind, visited South Africa as part of a twoweek arms sales drive in the region. Rifkind pressed the case of British arms suppliers, including Yarrow shipbuilders, seeking a contract for four corvettes; British Aerospace, marketing its Hawk trainer as a replacement for South Africa's Impala; and Westland, offering its Lynx helicopters for the new corvettes (Financial Times 11 April 1995). Similarly, from 1991 Britain sold eighty Vickers battle tanks, CS gas and rubber bullets, and issued over thirty export licences for non-lethal military equipment, to Nigeria's military junta, many of which were in defiance of European Political Cooperation agreements to suspend military cooperation with Nigeria (Economist 8 July 1995: 60). And in Sierra Leone, Major's government was accused of offering a military advisor to the military junta government for six months from April 1995; a procurement expert to study defence purchase problems; and a short-term training team for senior officers in early 1995. Simultaneously, a contingent of ex-Gurkhas was helping to train the Sierra Leone army (Economist 8 July 1995: 60). Nor was Major's government fully committed to peacekeeping in Africa. In Somalia, for example, the British government declined to commit troops to either UNOSOM I or II, yet Douglas Hurd was quite happy to call for others to establish a UN 'trusteeship' over the country (Olsen 1997: 312). The government was also unable and apparently unwilling to prevent British mercenaries operating on the continent, such as those who provided security for certain mining complexes in Zaire as well as propping up the tottering regime of Mobutu Sese Seko (Africa Confidential 13 December 1996).

However, arguably the biggest stains on the Major government's attempts to promote peace emerged from its failure to respond effectively to two crises in Africa's Great Lakes region. First, Britain, along with the rest of international 
society, ignored what the US Committee for Refugees called a 'slow-motion coup' in Burundi that began in October 1993 and in which democratically elected president Melchior Ndadaye was killed. This sparked off a wave of violence, which according to Amnesty International left approximately 100,000 people dead by January 1994 and saw thousands of Hutu civilians ethnically cleansed from the country's capital city, Bujumbura. In response, the UN Security Council sent a small number of civilian observers but refused to offer military assistance to the stricken country. Apart from the allocation of some $£ 4.5 \mathrm{~m}$ of bilateral and emergency aid between 1993 and 1996, the British government has remained largely indifferent to the persistent violence in Burundi since 1993, preferring regional actors to find their own solutions. Since Nelson Mandela's retirement as president in 1999, South Africa has assumed the role of leading international mediator. Six months after Burundi's slow-motion coup began, British officials in Whitehall and the UN were making the extraordinary argument that responding to genocide in Rwanda was less important than ensuring the credibility of UN peacekeeping operations (Melvern 2000: 227-38). Not only did this line of reasoning assume that ignoring genocide would boost the UN's flagging credibility after the debacle in Somalia but it reinforced the signal that, in Africa at least, the British government was not prepared to put its own troops into harm's way for the cause of peace. Rwanda was considered an unimportant country that fell well outside Britain's zone of interest. As The Economist put it, Rwanda was apparently 'too difficult, too remote, maybe too black' and suffered because its 'agony was not played out on television' (7 May 1994: 15). The country also suffered from the political fallout of the interventions in Somalia, with politicians subsequently reluctant to become entangled in another African civil war. After the genocide was over, Britain deployed over 600 troops to the country for three months to provide technical and humanitarian assistance and established a diplomatic embassy. Before the genocide Britain had only a non-resident ambassador to both Burundi and Rwanda based in Uganda. This was indicative of the traditional view that Britain had very little to do with these countries.

In comparison with the Conservatives, the Blair government has engaged in far more initiatives intended to promote peace on the continent. These activities can be divided into those designed to respond to violent conflict and those designed to prevent it. Like the Conservatives, however, New Labour has pursued policies that have been selective and at times selfish and contradictory. Selectivity has been evident in the concentration of criticism on some fraudulent elections (as in Zimbabwe) while virtually ignoring others (as in Zambia and Madagascar). Selfishness was prominent in Kenya where, in the wake of the US-led 'war on terrorism' and the search for Islamic militants in Nairobi and Mombassa, New Labour decided to ignore then President Daniel arap Moi's poor human rights record in favour of renewing a military cooperation agreement that allowed British troops to use bases in the country (Africa Confidential 21 December 2001). And there have also 
been contradictions, as in the case of pushing for peace in the DRC but refusing to openly criticize friendly states such as Yoweri Museveni's Uganda and Paul Kagame's Rwanda for their involvement in the war.

New Labour has employed a variety of policies in response to war in Africa, including diplomacy and enforcement measures such as sanctions and military intervention. Politically, Blair's government has sought to manage conflicts by providing support for conflict resolution, and by consolidating peace through assisting in the disarmament, demobilization and reintegration of former combatants and boosting Africa's own peacekeeping capacity (Lloyd 1999). These activities have involved the Ministry of Defence (MoD) and DFID as well as the FCO. In relation to the military dimensions of its strategy, New Labour arrived in power keen to distance itself from the Major government's approach. To this end a Strategic Defence Review was quickly convened that reported in 1998. Among other things, this acknowledged the need to restructure Britain's armed forces to conduct small- or mid-scale power projection operations, such as the one deployed to Sierra Leone in 2000. This was also a theme of New Labour's attempts to develop a common European Security and Defence Policy with other EU member states, notably France and Germany. Declared hypothetically operational in December 2001, the Security and Defence Policy includes scope for a European Rapid Reaction Force (ERRF) of up to 60,000 troops deployable within sixty days' notice and sustainable for up to one year. Although the ERRF's exact remit, in terms of both function and geography, remains unclear, officials from Britain (and other EU states) have not ruled out the possibility of it operating in Africa.

Blair's government has also used so-called smart sanctions as a tool for promoting peace in Africa, especially to help reduce the trade in conflict goods such as oil, timber and diamonds in Angola, DRC, Liberia and Sierra Leone. In Angola, for example, Blair's government pledged to help isolate and defeat Jonas Savimbi's UNITA (Hain 1999b). Similarly, evidence presented by Robin Cook of Charles Taylor's support for the Revolutionary United Front of Sierra Leone and other insurgent groups in the region was instrumental in getting EU ministers to agree to freeze a two-year development aid programme for Liberia in 1998 and UN sanctions imposed in May 2001, which included a ban on the import of rough diamonds from the country. And in response to the ongoing crisis in Zimbabwe, Britain has also (with one or two problems) ceased its military cooperation with the country and, along with the EU and US, imposed smart sanctions upon certain members of Robert Mugabe's ZANU-PF regime (Taylor and Williams 2002).

On the negative side, one area where New Labour has received sustained criticism is over its continued arms sales to Africa, which the Campaign Against the Arms Trade estimates will exceed US\$200m in 2003. In 1999, for instance, the government granted 970 single individual export licences in the small arms category, including exports to Eritrea, Kenya and Zimbabwe (CAAT 2001). Similarly, like its predecessors, Blair's government has continued to aggressively court South African arms contracts; BAE Systems 
and other British businessmen were alleged to have supplied spare parts for Zimbabwe's fleet of Hawk jets and other material while over 12,000 of Mugabe's troops waged war in the DRC (Africa Confidential 25 October 2002); and British-made weapons found their way into the hands of child soldiers fighting in Sierra Leone's war (Daily Mail 30 May 2000).

However, the incident that attracted the most media attention was the socalled 'Arms-to-Africa' affair in which the FCO was found to have colluded with the military consultancy firm Sandline International to bring 30 tonnes of arms and ammunition into Sierra Leone in contravention of the UN arms embargo (see FAC 1999). Although many Sierra Leonean civilians welcomed the results of this policy, it raised two dilemmas for Blair's government. First, if it is serious about promoting peace in Africa it has to make some tough decisions in relation to its domestic arms industry, which supports 45,000 jobs directly and another 45,000 indirectly (Goodie 2002). To date, there is little indication that the government intends to purposely reduce these numbers. Second, it raised the issue of what to do about British mercenaries and private military companies. Much to the embarrassment of the FCO, the point was reiterated when, during the war in the DRC, Avient, a company run by a British businessman, supplied military assistance to the DRC's air force against a variety of rebels (Financial Times 17 April 2001). In response, the government released a Green Paper in February 2002 discussing its plans for regulating the private military industry. However, British mercenaries have continued to operate in Africa, most recently in the Ivory Coast's ongoing conflict (Guardian 22 February 2003).

The biggest practical test of New Labour's ideas about promoting peace and security in Africa is its ongoing engagement with Sierra Leone. After years of neglecting the country's war under the Conservatives, New Labour became deeply involved in the diplomatic efforts to end the conflict and intervened militarily in May and again in October 2000. In retrospect, the British government's decision can be understood as deriving from a mixture of five imperatives: to protect British citizens; to avert a humanitarian crisis like that which had engulfed Freetown in January 1999; to defend the democratically elected government of President Kabbah; to live up to its stated foreign policy principles; and to support the UN operation, UNAMSIL, to carry out its mandate (Williams 2001). The presence of British troops helped to stabilize the UN force in and around Freetown, and as a semblance of order was restored to parts of the country the British scaled back their military contingent. Since then, the British have concentrated upon supporting President Kabbah politically, establishing a truth and reconciliation commission and a special court (despite significant criticism, see Penfold 2002), and undertaking security sector reform.

Soon after the intervention in Sierra Leone and as part of its Africa Conflict Prevention Initiative, Blair's government elaborated its position on the changing nature and extent of conflict in Africa during the 1990s and identified what it saw as the root, secondary and tertiary causes of conflict on the continent (UK Government 2001). The root causes of conflict were identified 
as inequality between groups, economic decline, state collapse and a history of resolving problems by violent means. Secondary causes included widespread unemployment, lack of education, population pressure, 'the abuse of ethnicity', and the availability of small arms. Tertiary causes that hinder conflict resolution efforts included the regional and interlocking nature of many conflicts, a lack of external guarantors to peace processes, inadequate and inappropriate mediation, and misplaced humanitarian assistance. The government sees its own role as being multidimensional and comprising of both short- and long-term commitments. The most pressing are considered to be enhancing small arms and light weapons controls; encouraging responsible investment practices in conflict zones; reducing the exploitation of mineral resources for the purposes of war; promoting inclusive forms of government; supporting security sector reform; and providing assistance to Africa's regional organizations, especially in relation to peacekeeping capacity (UK Government 2001: 22). However, this analysis has been criticized for containing little that is innovative; ignoring the globalized nature of war in Africa; analysing the continent as if it was somehow disconnected from the rest of the world and in a permanent state of crisis; and for generating inflated expectations about what Britain can 'deliver' (Ero 2001: 60-1).

More positively, New Labour's policy statements have consistently emphasized that 'the most effective way to end human rights violations in conflict is by preventing conflict in the first place' (FCO 1998: 19). The British approach to conflict prevention concentrates on five areas for action: addressing the root causes of conflict by fighting poverty and promoting sustainable development; supporting forms of governance that have the consent of local people; curbing the flow of small arms and light weapons; preventing the trade of conflict goods, including diamonds; and countering the emerging 'culture of impunity' for those who break international humanitarian law (Cook 1999). DFID has played a particularly important part in developing this approach and has also had significant input into the wider OECD strategies for preventing violent conflict. In 1998 DFID established a Conflict and Humanitarian Affairs Department as the administrative expression of its move towards integrating conflict and development objectives (Kapila and Wermester 2002: 303). The focus on conflict prevention has also highlighted the need for a 'joined-up' foreign policy where different ministries and departments work with, not against, each other. It has also highlighted the need for British and other TNCs to behave responsibly in conflict situations (Kapila and Wermester 2002: 306-7). One practical result of this line of thinking has been the establishment of the Africa Conflict Prevention Initiative led by DFID, which became formally active in spring 2001 and allocated approximately $£ 50 \mathrm{~m}$ per year between 2001 and 2004. The aim is 'to ensure that the government gets a maximum return on the resources it allocates to conflict-prevention activities' (Ero 2001: 59). It is also designed to fit into the British government's philosophy that offering combatants a brighter economic future is a necessary part of building peace in Africa. 


\section{Promoting prosperity?}

As what Napoleon described as 'a nation of shopkeepers' it was not surprising that, during the Cold War, Britain's bilateral relations with African states were often preoccupied with the protection of trade and investment. It was also a position energetically pushed by the major British TNCs active in Africa, including Lonrho, Unilever, ICI, British Petroleum, Marconi and British banks such as Standard Chartered and Barclays, which currently have full retail and corporate banking facilities in twelve and ten African states respectively. After the Cold War, Britain's attempts to encourage economic growth in Africa have been through the promotion of free trade; encouraging profitable foreign direct investment (FDI); reducing the burden of debt; and providing development aid.

Both the Conservative and Labour governments have subscribed to liberal assumptions about the relationship between economics and politics, and the ostensibly mutually beneficial nature of international trade and FDI. This stance has frequently met with criticism from a variety of African states seeking fairer structures of international trade and left British governments with little space to criticize the negative social consequences of economic liberalism in states such as Zambia and South Africa (Abrahamsen and Williams 2001: 254-8).

In practical terms, there has been an 'overwhelming predominance of South Africa in Britain's commercial links with the continent', with the country consistently representing over 40 per cent of Britain's exports and imports to and from the continent throughout the post-Cold War period (Styan 1996: 271). Only South Africa has consistently been among Britain's top twenty countries for imports (between 2001 and 2004 its average growth rate in this regard was second only to China) while no African state has figured in the top twenty for exports. During the Conservative years, without South Africa, sub-Saharan Africa represented less than 2 per cent of all imports into Britain and less than 3 per cent of British exports (Styan 1996: 271). As with peace initiatives, Britain's other commercial relationships have remained predominantly within Commonwealth Africa, although recent signs indicate that British business is seeking to expand beyond this sphere.

British exporters have been given state support through a variety of mechanisms including the Commonwealth Development Corporation or by the Department of Trade and Industry (DTI) and the FCO through Trade Partners UK. The latter has some 2,000 staff worldwide dedicated to helping British business compete successfully across the globe. In addition, the government's trade promotion policy is guided by advice from 200 businesses that serve on the British Overseas Trade Board.

Between 1994 and 2001, compared to the world's other major regions, the annual average growth rate and total of British exports to sub-Saharan Africa were higher only than those of British exports to South America. In contrast, British imports from sub-Saharan Africa were larger than those from North Africa and the Middle East and South America, and grew by an annual average 
growth rate of 12.26 per cent, which was second only to eastern Europe (see Table 2.1). In other words, there are signs that Africa is becoming of increasing economic significance to Britain. By 2001 the five biggest African states exporting goods to Britain were (in descending order) South Africa, Nigeria, Kenya, Ghana and Angola (Britain's largest market outside Commonwealth Africa). For British imports the top five African states were (again in descending order) South Africa, Botswana, Mauritius, Namibia and Kenya.

British business is currently most active in seeking openings in the oil, gas and other natural resources sectors. Along with the larger markets, for instance, there has recently been heightened activity in Congo-Brazzaville's oil sector and the prospect of more to come with offshore discoveries all along the Gulf of Guinea. British Petroleum, for example, has also invested in prospecting for gas in Mozambique and seen its profits there increase fivefold over the last three years. The company now has operations in thirteen African states mainly in southern Africa, employs about 1,300 people in South Africa alone, and expects to invest approximately \$7bn in Angola before 2010. Outside the natural resources sector, British TNCs, with the help of the British state, have looked to the so-called 'gateway economies'. The largest and most trusted gateway into southern Africa's market of 185 million people is South Africa. Here the UK-South Africa Partnership Programme has helped to build partnerships between South African and British companies. However, since the end of apartheid, South African companies have launched increasingly successful ventures throughout the continent, in many places, including Kenya and Uganda, at the expense of British companies. Partly as a result of this, British TNCs have started to look for gateways into francophone West Africa. Traditionally, Ghana has fulfilled this role, but more recently Cameroon, Senegal and the Ivory Coast have been actively courted. In the Ivory Coast, for example, the British government and private business worked in tandem to win the first major contract for a British company, TCI, in 2000. Similarly, in Cameroon a variety of companies including Guinness, Shell, Standard Chartered Bank and British American Tobacco have sought to use the country as a gateway into West Africa.

As the dominance of neo-liberal economic theories grew after the disintegration of the Soviet Union, many African states (especially Egypt, Mauritius, South Africa and Tunisia) initiated economic reforms aimed at increasing the role of the private sector and attracting FDI. These reforms included regulatory frameworks for FDI, trade liberalization, bilateral investment treaties and

Table 2.1 British trade relations with sub-Saharan Africa (in $£$ millions)

\begin{tabular}{lllllllll}
\hline & 1994 & 1995 & 1996 & 1997 & 1998 & 1999 & 2000 & 2001 \\
Exports & 3,137 & 3,664 & 3,840 & 3,574 & 3,312 & 2,961 & 3,170 & 3,466 \\
Imports & 2,248 & 2,552 & 2,885 & 2,840 & 2,865 & 3,242 & 4,201 & 5,669
\end{tabular}


double taxation treaties (UNCTAD 1999). The recent FDI frontrunners in Africa have been Botswana, Equatorial Guinea, Ghana, Mozambique, Namibia, Tunisia and Uganda, with most analysts agreeing that 'natural resources have been among the main determinants for the attraction of FDI to almost all the frontrunners' (UNCTAD 1999: 25).

The need to promote private investment in Africa has been a persistent theme in both the Major and Blair governments. Although there was a significant period of disinvestments by British companies immediately after the Cold War, Britain remains among the largest investors in Africa, with cumulative flows between 1988 and 1997 totalling approximately $\$ 5,458 \mathrm{~m}$ (UNCTAD 1999: 52). British FDI stock in Africa is no longer concentrated in the primary sector but instead embraces the manufacturing and services sectors. In 1989 the sectoral composition of British FDI stock in the continent was 37 per cent primary, 37 per cent secondary and 26 per cent tertiary. These figures had remained constant when New Labour took office in 1997 (UNCTAD 1999: 16). British investments have proved very profitable, with the net income accrued between 1989 and 1995 in sub-Saharan Africa (excluding Nigeria) increasing by 60 per cent (UNCTAD 1999: 17). To encourage more private investors, successive British governments have emphasized the need for African states to adopt 'good governance' and neo-liberal economic reforms. To this end, by January 1999 the British government had signed eighteen bilateral investment treaties ${ }^{4}$ and twenty-nine double taxation treaties ${ }^{5}$ with African states in an attempt to build environments conducive to FDI by British companies (UNCTAD 1999: 48-51). While the profits that have accrued to British firms as a result of these initiatives are obvious, the benefits to ordinary Africans are far from clear.

In relation to debt relief it was the Conservative government that in September 1990 first announced its intention to cancel two-thirds of the official debts of fifteen of its poor African debtors, so long as they kept to IMF rules (Economist 22 May 1993: 66). Since then, a complicated series of initiatives have been proposed. These culminated in the British government (led on this issue by the Chancellor, Gordon Brown, and International Development Secretary Clare Short) eventually settling on the terms of debt relief and/or cancellation provided the debtor states concerned continued to adopt neoliberal economic reforms and abide by the World Bank's definition of 'good governance'. In practice, however, most heavily indebted African states are yet to see the supposed benefits of this relief under either the World Bank's reformed Heavily Indebted Poor Countries (HIPC) initiative or the G-7's Cologne Initiative (1999). Indeed, some African states have actually seen their levels of debt increase with the implementation of these schemes. Uganda, for instance, whose current debt stands at approximately $\$ 3,409 \mathrm{~m}$, saw its terms of relief persistently altered by its creditors until it was actually worse off than before (Dixon and Williams 2001: 167-8). Similarly, in 2003 Ethiopia, Malawi, Mozambique and Zambia had to pay approximately $\$ 325 \mathrm{~m}$ to the IMF, World Bank and Paris Club states even as they were experiencing famines 
(Guardian 6 January 2003). Upon reflection, the British government's actions on debt relief have remained largely symbolic. And with the closing down of the NGO coalition Jubilee 2000 in the new millennium, the intense levels of public protest surrounding the issue have subsided as international attention has become preoccupied with the US-led 'war on terrorism'.

On the issue of aid, it appears that after the Cold War the motives of the major donors in sub-Saharan Africa have been fivefold: to promote development in recipient states; diplomatic - as a tool of foreign policy (indeed, aid was a useful tool to ease Britain's withdrawal from active engagement in the region); commercial; cultural - including promoting language, religion and values; and humanitarian (Lancaster 2000: 213-16). However, aid to Africa has tended to be the least effective of any aid worldwide. Certainly, it has been the least sustainable, often with fewer than half of aid-funded projects surviving after aid was terminated. The least effective types of projects have been those involving 'complex interventions', requiring the management of multiple activities and organizational actors and/or social and political changes within African societies to be effective and sustained (Lancaster 2000: 225).

Under the Major government, aid programmes to Africa in the forms of cash grants and concessional loans were reduced from $£ 636 \mathrm{~m}$ in 1989 to $£ 563 \mathrm{~m}$ in 1995 . This was in line with a reduction in Britain's overall aid budget from 0.31 per cent of Gross National Income (GNI) in 1989 to 0.26 per cent in 1997. The Blair government in contrast increased the size of the aid budget and bilateral programmes to Africa. The former rose to 0.3 per cent of GNI in 2001 and is apparently set to rise to 0.4 per cent by 2005-6 (DFID Press Release 3 April 2003). However, these levels are still only equivalent to 1989 levels and fall well short of the UN's recommended target of 0.7 per cent. Currently (2001-2), excluding humanitarian assistance, three of the top five recipients of DFID's expenditure were African, ${ }^{6}$ and subSaharan Africa receives 43 per cent of all bilateral aid allocable by region compared with 36 per cent going to Asia (DFID Press Release 14 October 2002). (See Table 2.2.)

Table 2.2 British bilateral aid: top ten African recipients, 1999-2000 (£ millions)

\begin{tabular}{ll}
\hline Uganda & 81 \\
Tanzania & 64 \\
Ghana & 48 \\
Malawi & 47 \\
Mozambique & 44 \\
Sierra Leone & 30 \\
South Africa & 30 \\
Kenya & 27 \\
Nigeria & 15 \\
Rwanda & 14.5
\end{tabular}

Source: Adapted from The Economist 23 February 2001: 35 
Under the New Labour government there has also been an increased tendency to channel development expenditure through civil society organizations, with $£ 191 \mathrm{~m}$ disbursed in this manner in 2001-2 (DFID Press Release 14 October 2002). DFID has also been keen to work more closely with the private sector, one significant example being the Emerging Africa Infrastructure Fund. Established in 2002 and led by DFID and the Standard Bank Group, this earmarked $\$ 305 \mathrm{~m}$ of public and private monies for projects including power generation, telecommunications, transportation and water facilities (DFID Press Release 30 January 2002).

Currently, Blair's government is trying to tie the themes of peace and prosperity together by supporting the New Partnership for Africa's Development (NEPAD) launched by African states in October 2001. Britain has endorsed NEPAD's liberal rationale and stressed two important strengths of the initiative. First, because it was designed by African states it is an example of Britain working in partnership with the continent rather than dictating the terms of the relationship. Second, it provides a framework for a variety of international actors, including the G-8, to cooperate across a broad range of areas such as peace and security, governance, investment, economic growth, development, agriculture, debt relief, health and information. Blair's brief tour of Nigeria, Senegal, Ghana and Sierra Leone in February 2002 was used partly to reiterate his government's support for the vision set out in NEPAD. The following month, however, the political storm surrounding Mugabe's 'victory' in Zimbabwe's presidential elections and the support he gained from many African states led British officials to question NEPAD's viability if its proponents failed to condemn Zimbabwe's plunge into crisis. Then, in June, Blair faced Japanese and US resistance to the plan at the G-8 summit in Kananaskis, Canada, despite the fact that NEPAD essentially endorses the G-8's version of the problems afflicting Africa and the necessary solutions (see Taylor and Nel 2002). Despite these problems NEPAD remains the current framework within which these issues will be addressed.

\section{Promoting democracy?}

After the World Bank's 1989 report Sub-Saharan Africa: From Crisis to Sustainable Growth, democracy or 'good governance' became the buzzwords of development discourse (Abrahamsen and Williams 2001: 258-60). Within a year most major state donors and international organizations made development assistance conditional on democratic reforms.

As noted above, Britain adopted such a stance in mid-1990 and practical evidence of the new policy was soon visible in the government's decision to cut its aid programmes to Sudan (1991), Kenya (1991) and Malawi (1992). A similar decision was taken through the EU to cut aid to The Gambia following the military coup that deposed President Dawda Jawara in July 1994. Again, however, Major's government applied this supposed principle selectively. Jerry Rawlings' Ghana and Yoweri Museveni's Uganda, for 
example, did not face such sanctions despite refusing to adopt liberal democratic reforms. Indeed, because it adhered to the prerequisites of World Bank structural adjustment, Ghana was even dubbed 'the darling of British aid overseers' and received more aid than any other African state except Zimbabwe (Economist 29 May 1993: 66). Similarly, little external criticism of Uganda's one-party movement for democracy has appeared because it too has followed the official adjustment rules.

More recently, the biggest tests of this position have been developments in Nigeria, Zimbabwe and, to a lesser extent, Rwanda. However, like the Conservatives, New Labour has also imposed sanctions on weak states while turning a blind eye to the vagaries of friends or stronger states. In Togo, for example, the EU (pushed by Britain and Germany) suspended aid following President Gnassingbé Eyadéma's fraudulent elections in June 1998 (Africa Confidential 2 April 1999).

In Nigeria, on the other hand, Britain's oil and other commercial interests were consistently considered paramount. Throughout the early 1990s, Nigeria was Britain's second largest export market in Africa, accounting for $£ 457.9 \mathrm{~m}$ of British exports in 1994 (Hansard 16 May 1995: col. 156). It was thus not especially surprising that when in 1995 General Sani Abacha announced the postponement of elections for more than three years, Britain's official reaction was to describe this as 'disappointing' (Economist 28 October 1995). Concerns about the military junta had not caused Britain to suspend its aid programme or stop selling weapons to Nigeria or supporting (politically and financially) its activities in both Liberia and Sierra Leone under the cover of ECOMOG. Following the execution of nine Ogoni activists in late 1995, Major's government did withdraw its ambassador from Nigeria, supported Nigeria's suspension from the Commonwealth and decided to terminate its arms sales to the country. However, although Britain supported an arms embargo against Abacha's regime, for commercial reasons it did not support the idea of oil sanctions proposed by Germany and the Nordic states. In Zimbabwe's case, Blair's government imposed a variety of sanctions bilaterally and through the EU after the country's parliamentary elections in 2000 in protest at Robert Mugabe's increasingly authoritarian rule (Taylor and Williams 2002).

For both the Major and Blair governments, democracy appears as an unproblematic concept with little attention paid to its inherently contested and controversial nature. In Africa, as elsewhere, democracy means very different things to different people and these competing definitions have been glossed over by successive British governments (Abrahamsen 2000). Both Conservative and Labour governments have advocated a particular form of multi-party liberal democracy that is said to be compatible with economic liberalization. Although this conception of democracy has appealed to many African elites, the continent's poorest people have usually defined democracy as including the provision of social and economic rights as well as civil and political ones. 


\section{Conclusion}

This analysis suggests that Britain has a mixed record in terms of promoting peace, prosperity and democracy in Africa after the Cold War, with both Conservative and Labour governments pursuing selective and sometimes counterproductive policies. The brand of liberal internationalism exported by successive British governments has won favour with many African statesmen but has far fewer supporters among the continent's impoverished majority. This is at least partly because neither the Major nor the Blair governments have seriously addressed the tensions within their philosophical approach as it applies to Africa, particularly how neo-liberal economic policies have contributed to war, poverty and authoritarianism.

African affairs are undoubtedly higher up the British foreign policy agenda than they were immediately after the Cold War's end but it is inaccurate to suggest that, with the occasional exception, they occupy anything other than a marginal position in British politics more generally. Arguably, however, dramatic changes in Britain's policy towards Africa require substantial changes to be introduced at home. Not least, the British government must take some difficult decisions on issues like its domestic arms industry and invest the time and resources to explain to their electorates why Africa's predicament is an important political issue for Britons. These issues are important because, for all the talk of disengagement, Britain continues to play a significant part in African affairs through its bilateral relations, the activities of British TNCs and NGOs, and through its membership of the major multilateral institutions, most notably the UN, IMF, World Bank, World Trade Organization, G-8, Commonwealth and the EU. At present, however, the nature of Britain's relationship with Africa appears still to revolve around extracting profits and preventing 'their' problems ending up 'over here'. In this sense, Britain has still not moved beyond a damage limitation approach.

\section{Notes}

1 I would like to thank Rita Abrahamsen, Michael Kargbo and Ian Taylor for their comments on an earlier draft.

2 In 2002 Britain had thirty embassies and High Commissions in Africa with a total of over 1,750 staff, a total second only to the Asian Directorate within the FCO. There were thirty-one African diplomatic missions in London.

3 Author's interview with British official, February 2003.

4 Benin, Burundi, Cameroon, Congo, Egypt, Ghana, Ivory Coast, Lesotho, Mauritius, Morocco, Nigeria, Senegal, Sierra Leone, South Africa, Swaziland, Tunisia, Tanzania and Zimbabwe.

5 Algeria, Botswana, Cameroon, Congo, Egypt, Ethiopia, The Gambia, Ghana (x3), Ivory Coast, Kenya, Lesotho (x2), Malawi, Mauritius, Morocco, Namibia, Nigeria, Sierra Leone, South Africa (x2), Sudan, Swaziland, Tunisia, Uganda (x2), Zambia, Zimbabwe.

6 India (£180m), Uganda (£68m), Tanzania (£65m), Bangladesh (£61m) and Ghana (£55m). 


\section{References}

Unless otherwise stated, all speeches by British government officials and government publications are available at www.fco.gov.uk

Abrahamsen, R. (2000) Disciplining Democracy: Development Discourse and Good Governance in Africa, London: Zed Books.

(2002) 'Blair's Africa: Securitisation after 11 September', paper presented to the African Studies Association of the UK biennial conference, University of Birmingham, 9-11 September.

Abrahamsen, R. and P. Williams (2001) 'Ethics and Foreign Policy: The Antinomies of New Labour's "Third Way" in Sub-Saharan Africa', Political Studies, 49: 249-64.

(2002) 'Britain and Southern Africa: A Third Way or Business as Usual?' in K. Adar and R. Ajulu (eds) Globalization and Emerging Trends in African States Foreign Policy-Making Process, Aldershot: Ashgate, pp. 307-28.

Blair, T. (1997) 'Principles of a Modern British Foreign Policy', speech at the Lord Mayor's banquet, London, 10 November.

(1998) The Third Way: New Politics for a New Century, London: Fabian Society Pamphlet 588.

_ (2001) Speech to Labour Party annual conference, Brighton, 2 October.

CAAT (2001) 'Labour's Hypocrisy over Small Arms', news release, 13 February. www.caat.org

Clapham, C. (1996) Africa and the International System: The Politics of State Survival, Cambridge: Cambridge University Press.

Cook, R. (1998) 'Promoting Peace and Prosperity in Africa', speech to the UN Security Council, 24 September.

(1999) 'Conflict Prevention in the Modern World', speech to the 54th session of the UN General Assembly, New York, 21 September.

Dixon, R. and P. Williams (2001) 'Tough on Debt, Tough on the Causes of Debt? New Labour's Third Way Foreign Policy', British Journal of Politics and International Relations, 3, 2: 150-72.

Ero, C. (2001) 'A Critical Assessment of Britain's Africa Policy', Conflict, Security and Development, 1, 2: 51-71.

FAC (Foreign Affairs Select Committee) (1999) Second Report: Sierra Leone, London: House of Commons, 9 February.

FCO (1995) Angola: The Long Road to Recovery, FCO Briefing Paper, October. (1998) Annual Report on Human Rights, London: FCO and DFID.

Goodie, I. (2002) The Employment Consequences of a Ban on Arms Exports, London: CAAT Report, September. www.caat.org

Green Paper (2002) Private Military Companies: Options for Regulation, London: House of Commons.

Hain, P. (1999a) 'Africa: Backing Success', speech at the 'Challenges for Governance in Africa' conference, Wilton Park, 13 September.

(1999b) 'Angola Needs Our Help', speech to the Action for Southern Africa Annual Conference, London, 20 November.

Hurd, D. (1990) 'Prospects for Africa in the 1990s', speech to the Overseas Development Institute, London, 6 June.

Kahler, M. (ed.) (1997) Liberalization and Foreign Policy, New York: Columbia University Press. 
Kapila, M. and K. Wermester (2002) 'Development and Conflict: New Approaches in the United Kingdom' in F. O. Hampson and D. M. Malone (eds) From Reaction to Conflict Prevention: Opportunities for the UN System, Boulder, CO: Lynne Rienner, pp. 297-320.

Khadiagala, G. M. (2000) 'Europe in Africa's Renewal: Beyond Postcolonialism' in J. W. Harbeson and D. Rothchild (eds) Africa in World Politics: The African State System in Flux, Oxford: Westview Press, 3rd edn, pp. 83-109.

Lancaster, C. (2000) 'Africa in World Affairs' in J. W. Harbeson and D. Rothchild (eds) Africa in World Politics: The African State System in Flux, Oxford: Westview Press, 3rd edn, pp. 208-34.

Lloyd, T. (1999) Speech to the Africa Day Conference, Lancaster House, London, 26 May.

McNulty, M. (1999) 'Media, Ethnicization and the International Response to War and Genocide in Rwanda' in T. Allen and J. Seaton (eds) The Media of Conflict, London: Zed Books, pp. 268-86.

Mayall, J. (1986) 'Britain and Anglophone Africa' in A. Sesay (ed.) Africa and Europe: From Partition to Interdependence or Dependence?, London: Croom Helm, pp. 52-74.

Melvern, L. (2000) A People Betrayed: The Role of the West in Rwanda's Genocide, London: Zed Books.

- (2001) 'Missing the Story: The Media and the Rwandan Genocide', Contemporary Security Policy, 22, 3: 91-106.

Olsen, G. R. (1997) 'Western Europe's Relations with Africa since the End of the Cold War', Journal of Modern African Studies, 35: 299-319.

Penfold, P. (2002) 'Will Justice Help Peace?', The World Today, 58, 11: 21-3.

Rifkind, M. (1996) 'Africa - Time to Take Another Look', speech to the Royal Institute of International Affairs, 28 November, cited in RUSI, Documents on British Foreign and Security Policy: Vol. I: 1995-1997, London: TSO (1998), pp. 629-36.

Styan, D. (1996) 'Does Britain Have an African Policy?' in L'Afrique Politique, Paris: Karthala, pp. 261-86.

Taylor, I. and P. Nel (2002) " "Getting the Rhetoric Right", Getting the Strategy Wrong: "New Africa", Globalization and the Confines of Elite Reformism', Third World Quarterly, 23: 163-80.

Taylor, I. and P. Williams (2002)'The Limits of Engagement: British Foreign Policy and the Crisis in Zimbabwe', International Affairs, 78: 547-65.

UK Government (2001) The Causes of Conflict in Africa, London: DFID, FCO, MoD Consultation Document.

UNCTAD (1999) Foreign Direct Investment in Africa: Performance and Potential, New York and Geneva: UNCTAD/ITE/IIT/Misc. 15.

Wallace, W. (1994) 'Foreign Policy' in D. Kavanagh and A. Seldon (eds) The Major Effect, London: Macmillan, pp. 283-300.

Williams, P. (2001) 'Fighting for Freetown: British Military Intervention in Sierra Leone', Contemporary Security Policy, 22, 3: 140-68.

_ (2002) 'The Rise and Fall of the "Ethical Dimension": Presentation and Practice in New Labour's Foreign Policy', Cambridge Review of International Affairs, 15, 1: 53-63. 